\title{
Occupational exposure and defects of the central nervous system in offspring: review
}

\author{
N Roeleveld, G A Zielhuis, F Gabreëls
}

\begin{abstract}
A study of published work was carried out in a search for evidence of a causal role for parental occupational exposure in the origin of structural and functional defects of the central nervous system (CNS) in children. Studies that consider this topic are scarce and mostly refer to broad categories of exposures and effects. Non-occupational studies referring to environmental exposure of humans and studies on experimental animals were also reviewed. The studies on animals provided straightforward evidence about morphological and behavioural abnormalities resulting from some agents used occupationally. The studies on humans yielded a scala of defects that could be ascribed to exposure to high doses of various agents in the environment. Evidence for a causal role of occupational exposure has not been found, but a highly probable influence on the developing CNS is hypothesised for lead, methyl mercury, and ionising radiation. Parental occupational exposure to cadmium, organic solvents, anaesthetics, and pesticides may also play a part in causing defects of the CNS. Well designed future research is needed to test the above hypotheses.
\end{abstract}

The effects of occupational exposure on the nervous system of workers have gained increasing attention over the past 20 years. Exposure to heavy metals and organic solvents in particular have been shown to cause functional disturbances in both the peripheral nervous system (PNS) and central nervous system (CNS). As the developing CNS is more susceptible to exogenous influences then the mature nervous system, ${ }^{12}$ parental occupational exposure in the pre

Department of Epidemiology, Institute of Social Medicine, University of Nijmegen, The Netherlands N Roeleveld, G A Zielhuis

Interdisciplinary Child Neurology Centre, St Radboud University Hospital, Nijmegen, The Netherlands

F Gabreëls and postnatal periods has been associated with defects of the CNS in offspring. Exposure to teratogens in the embryonic period may lead to structural malformations or to functional defects of the CNS at low doses. Fetal and postnatal exposure may affect the further growth and development of the CNS, mainly resulting in functional disturbances. ${ }^{13-6} 6$ Moreover, exposure to genotoxic chemicals and ionising radiation before conception may cause alterations in genetic material, ultimately expressed as structural or functional defects of the CNS in offspring. ${ }^{178}$ Evidence for these teratogenic effects is fairly strong for certain medical drugs, ionising radiation, and environmental pollutants accidentally occurring in high doses. ${ }^{6910}$ Effects of occupational exposure on the CNS in offspring, however, have rarely been described.

The aim of the present review was to find indica tions for a causal role of parental occupations exposure in the origin of defects of the CNS in children. To this end, publications on the teratogenic effects of agents used occupationally were extensively evaluated. Both structural and functional disturbances in the developing brain were considered.

\section{Material and methods}

To evaluate all the relevant publications, a search was conducted on occupational and also environmental exposure associated with defects of the CNS in children and in experimental animals. An online computer search on MEDLINE from 1981 to and including 1989, with the keywords (congenital) CNS diseases or abnormalities, behaviour, and mental retardation in association with teratogens, radiation, and environmental pollution or exposure produced a large number of original articles and reviews. Additional papers were traced through the references listed in the reviews and by browsing through the major journals on occupational and environmental health. A selection was made from more than 300 publications in accordance with the following inclusion criteria:

The paper referred to agents used in occupational settings.

Indications of structural or functional defects of the CNS in offspring were described in relation to prenatal or postnatal exposure. 
No major sources of bias were present in the study. The paper contained sufficient information to warrant conclusions.

Eighty four original articles and 37 reviews were selected. Only 35 papers, however, described a relation between certain occupations or occupational exposure and defects of the CNS; the other papers referred to studies on environmental exposure or to animal models; a great deal of caution is required when extrapolating from studies on laboratory animals to the human brain. Among the studies on humans, clinical series and case reports also have limited value for the estimation of effects and the effects of occupational and environmental exposure are best evaluated by epidemiological studies. ${ }^{11}$ Despite the lack of comparability between studies, all the papers that meet the criteria described above were included in the review. For most studies published before the $1980 \mathrm{~s}$, information from previously published reviews was used. All the papers were critically evaluated and the relative value of their results is discussed below. For the most important groups of agents the available evidence is summarised in the table. Finally, an appraisal is made of the influence of parental occupational exposure on the developing CNS.

\section{Teratogenic influences on the central nervous system}

The developing brain is at high risk of being affected by teratogenic agents because of its long lasting sensitive period, which extends from the beginning of organogenesis to the neonatal and infantile period; the vulnerability of undifferentiated neural cells; and lack of reproductive capacity of cerebral neurons. ${ }^{2}$ Teratogenic insults during the early embryonic period may cause gross structural malformations of the brain, such as anencephaly, meningocele, and hydrocephalus. During the developmental period, teratogens influence the formation and maturation of the neuronal and glial network by enhancing cell death and affecting proliferation, migration, and differentiation of cells, modifying the formation of neurites, synapses, and receptors; or causing hormonal and neurotransmitter disturbances. This influence can result in deficiencies in the number of cells, minute defects in brain architecture, or altered chemical composition of fetal brain tissue culminating in permanent functional disorders. ${ }^{1-35612}$ The most susceptible period is between 10 and 18 weeks of gestation during which intensive neuronal proliferation takes place, ${ }^{13}$ but the development of the brain extends into the neonatal and early childhood period. The time of exposure determines the nature of the abnormality, which depends on the specific CNS structures damaged. ${ }^{2312}$ Long term as well as brief exposure may pose a threat to the fetal brain, ${ }^{29}$ at doses that inflict only minor or transient damage to the CNS of the adult ${ }^{1}$ and which are far below the threshold limits for major malformations. ${ }^{512}$ During pregnancy, the placenta and the blood brain barrier of the fetus can be permeated by virtually any type of substance and the fetus can even concentrate teratogens. ${ }^{69}$ In the postnatal period, exposure to agents which concentrate in maternal milk can be substantial. ${ }^{14}$ Parental exposure to teratogenic agents preconception may cause genetic damage or other disturbances, which can be reflected in defects of the CNS in offspring. ${ }^{178}$ It is often difficult to assess whether prenatal or postnatal exposure or exposure preconception should be held responsible for a particular teratogenic effect.

\section{Defects of the central nervous system and parental exposure}

Publications on occupational exposure and reproductive defects have been reviewed many times, but effects on the CNS in offspring have only rarely been described. ${ }^{14-17}$ Some epidemiological studies related malformations of the CNS in general to mothers who were sales workers, ${ }^{18}$ industrial or construction workers, ${ }^{19}$ or who were employed in manufacturing industries. ${ }^{20}$ Moreover, an association was found between brain tumours in children and mothers exposed to chemicals, and fathers exposed to solvents and paint, ${ }^{212}$ working in the aircraft industry, ${ }^{22} 23$ or in the printing, chemical, or petroleum industries. ${ }^{24}$ The same applied to fathers working in industries with exposure to ionising radiation, ${ }^{25}$ in agriculture, in metal related jobs, or in the construction industry. ${ }^{26}$ The results for the fathers refer to exposure preconception but exposure during gestation and lactation-for instance, when fathers bring home soiled clothing - cannot be ruled out. Effects of specific occupational exposure on the developing brain were not described in these studies. In other (non-occupational) studies, indications of defects of the CNS in offspring were found after parental exposure to lead, mercury, cadmium, organic solvents, anaesthetics, pesticides, and ionising radiation. The available evidence for effects of these agents is reviewed in the sections below.

\section{LEAD}

Lead is a widely used industrial chemical. Occupational exposure to inorganic lead occurs in lead smelters, construction works, plastics production, jobs with paint and dyes, and in the printing, ceramics, galvanic, and electrotechnical industries. Inhalation of lead fumes and dust is the main route of exposure in adults, but ingestion might also occur. Organic lead is a major component of petrol, which can be inhaled as well as absorbed by the skin-for example, by workers in petrol stations and policemen working in polluted urban areas. Lead can easily pass the placenta and the blood brain barrier and it 
accumulates in brain tissue as well as in breast milk. ${ }^{1427} 28$ It may affect the fetal CNS by a direct toxic effect on neurones, inhibition of enzymes, or other biochemical changes. ${ }^{29} 30$ Studies in animals have shown gross and microscopic cerebral lesions in different species of animals exposed prenatally to lead,,$^{30}$ and behaviour and learning ability was shown to be impaired in other studies. ${ }^{323}$ Neurological deficits can also result from postnatal exposure, through breast feeding for example. ${ }^{34}$

In studies on humans, no gross structural malformations of the CNS were found in relation to exposure to lead. Studies on behavioural effects, however, are numerous. Prenatal exposure to lead was related to minor malformations, ${ }^{35}$ mental retardation, ${ }^{293637}$ and impaired cognitive development. ${ }^{38}$ Postnatal exposure and exposure to low lead concentrations in young children, often measured as the concentration of lead in blood or teeth, have been associated with impaired cognitive and behavioural functioning. ${ }^{39-4}$ It is also possible that the association can be reversed and functionally handicapped children may have a higher lead intake than healthy children. ${ }^{45}$

No studies were found that reported a relation between occupational exposure to lead and defects of the CNS in offspring. Animal experiments, however, and environmental studies on lead pollution provided substantial evidence that exposure to lead may affect the CNS both prenatally and postnatally. It may be hypothesised, therefore, that parental occupational exposure to lead could have adverse effects on the developing brain.

\section{MERCURY}

Compounds of mercury can be divided into organic, inorganic, and metallic mercury. Methylmercury is used in fungicides, wood and paper preservatives, and in the pharmaceutical industry together with other organic mercury compounds. In occupational situations, intake occurs through inhalation and skin contact. ${ }^{27}{ }^{28}$ Methylmercury passes easily through the placenta and accumulates in brain tissue. A reduction in brain size and disturbances in the cerebral architecture due to interference with neuronal growth and migration underlie the effects on the developing CNS.374647 Biochemical disturbances have also been found in studies on animals. ${ }^{48-50}$

Evidence for a teratogenetic role for methylmercury in defects of the CNS dates back to 1953 , when a disastrous outbreak of methylmercury poisoning occurred in Japan. Children of mothers who ate contaminated fish were born with fetal Minamata disease, a complex of neurological symptoms including cerebral palsy, ataxia, pathological reflexes, disturbed psychomotor development, and mental retardation often accompanied by microcephaly. ${ }^{51}$ Comparable symptoms were described in cases of acute prenatal exposure to methylmercury in Iraq. ${ }^{52}$ Studies with animals have shown the same defects with additional exencephaly, hydrocephalus, and behavioural disturbances. The effects of methylmercury on the fetal CNS of humans and animals have been extensively studied and reviewed. ${ }^{37} 463-57$ Differences in the intensity and duration of exposure and the stage of gestation at which exposure occurs, define the extent of the effect. Postnatal exposure to methylmercury through lactation may result in high tissue concentrations, but the infantile brain seems to be less vulnerable than the fetal brain. ${ }^{37} 46$

So far, occupational exposure to methylmercury has not been studied in relation to defects of the fetal CNS. Although the concentrations that reach the fetus or infant may be lower than in the above mentioned studies on humans, effects on the CNS certainly cannot be excluded.

Inorganic mercury compounds are sometimes present in pesticides and antiseptics and are used in the electrical appliance and paint industries. After inhalation or ingestion by the mother, they are rapidly dissolved in blood and deposited in the placenta. As a result, normal growth and development of the fetus may be reduced. Abnormal behavioural patterns have been observed in experimental animals. The full effect of inorganic mercury on the fetal CNS is as yet unknown, however..$^{535}$

Exposure to metallic mercury vapour may occur in the production of medical and scientific instruments, in the chemical and electrotechnical industries, in laboratories, and in dental surgeries. ${ }^{27} 2850$ Although it crosses the placenta rapidly and accumulates in the fetal brain, only a few studies have been carried out on the prenatal effects of mercury vapour. ${ }^{37}$ Two cases of severe congenital brain damage after occupational exposure to mercury vapour have been reported.$^{59}$ Because of nervous excitibility in adults, an exposure limit of $0.01 \mathrm{mg} / \mathrm{m}^{3}$ instead of 0.05 $\mathrm{mg} / \mathrm{m}^{3}$ is recommended for pregnant women..$^{58}$ Both inorganic and metallic mercury can be transferred through breast milk and be accumulated in the infant. Therefore, it also seems justified to expect effects on the CNS after exposure during the postnatal period. ${ }^{376}$

\section{CADMIUM}

Exposure to cadmium is associated with modern industrial processes such as the manufacture of batteries, alloys, paints, pesticides, plastics, and electroplating. Inhalation is the primary route of industrial exposure; smoking also makes a relatively large contribution to the body burden of cadmium. ${ }^{27} 28$ The placenta acts as a partial barrier to cadmium by accumulating it, but a small amount, nevertheless, reaches the fetus. It is also transferred to neonates through lactation. Some studies on animals reported exencephaly because of incomplete 
closure of the neural tube, or more insidious effects, such as increased vacuolation, haemorrhage, and behavioural and learning deficits. ${ }^{5560}$ There are no data available on the effects of prenatal or postnatal exposure to cadmium in humans, but in an epidemiological study, Marlowe et al found an association between mental retardation and raised concentrations of cadmium in hair in school age children. ${ }^{41}$ This indicates that cadmium may cause gross malformations as well as subtle behavioural effects, possibly mediated by the alteration of neurotransmitter systems. ${ }^{61}$

The main effect of exposure to cadmium is retardation of fetal growth, probably caused by changes in the structure of the placenta and a reduction in uteroplacental blood flow. ${ }^{514}$ This may be critical for the CNS, which is incapable of compensating for decrements in growth once the neural cells have matured. ${ }^{60}$ It is not possible to conclude whether any of the above mentioned effects can result from actual occupational exposure levels because of the imperfect information to date.

\section{ORGANIC SOLVENTS}

Organic solvents are widely used in industry for cleansing, degreasing, extraction, and as chemical intermediates. They are also used in laboratories and medical occupations and as components in paint, printing ink, and pesticides. Inhalation and absorption through the skin are the two major routes of exposure. Most solvents can pass the placental barrier; they are stored in fatty tissue and are excreted in breast milk. ${ }^{1427}$ No environmental studies or studies on experimental animals showed a relation between exposure to solvents and gross defects of the CNS. A few studies indicated subtle behavioural and biochemical effects in laboratory animals. ${ }^{62-64}$ Case reports were found on children with delayed development, microcephaly, and mental retardation resembling the fetal alcohol syndrome after toluene inhalation abuse by the mother. ${ }^{65} 66$

Several studies have been published on the neurobehavioural effects of occupational exposure to solvents in adults but studies on fetal or postnatal exposure are scarce and most of them fail to establish a relation with defects of the CNS. Maternal laboratory work was associated with an increased frequency of all congenital malformations in four studies. ${ }^{67-70}$ A relation between defects of the CNS and exposure to organic solvents during the first trimester of pregnancy was found in one casereferent study in Finland, with an odds ratio (OR) of $5 \cdot 5 .{ }^{71}$ When the study was extended for three more years, the association vanished. ${ }^{72} \mathrm{~A}$ recent study also failed to show an association between exposure to low concentrations of organic solvents in industry during gestation and adverse neurodevelopmental outcomes. ${ }^{73}$ A study based on occupational titles in
Denmark showed that malformations of the CNS were related to fathers exposed to solvents $(\mathrm{OR}=2 \cdot 8)$ and employed as painters $(\mathrm{OR}=4.9){ }^{74}$ This result is indirectly supported by the association demonstrated between painting and exposure to solvents and brain tumours in children. ${ }^{2122}$

There is little evidence that structural or functional defects of the CNS are due to parental occupational exposure. The number of studies is, however, small and the group of organic solvents represent a wide range of different agents. Bearing in mind the well known neurobehavioural effects on the mature nervous system, organic solvents may be regarded as potentially hazardous agents for the developing brain.

\section{ANAESTHETIC GASES}

The effects of anaesthetic gases such as halothane and nitrous oxide on reproductive outcome have been of great concern to anaesthesiologists, operating room personnel, surgeons, dentists, and dental assistants for many years. The studies on this topic have been reviewed before. ${ }^{11}{ }^{1455}$ 75-77 Various effects were reported including an increased frequency of congenital malformations; defects of the CNS were not mentioned separately, but one study showed a concentration of anomalies in the brain and possibly impaired intellectual development in children. ${ }^{78}$ This result was supported by studies on animals in which neurobehavioural changes were seen after prenatal and postnatal exposure to inhalant anaesthetics. ${ }^{79-81}$ The published material does not allow conclusions to be made about the potentially harmful effects of anaesthetic gases on the CNS in the fetus and infant.

\section{PESTICIDES}

Occupational exposure to pesticides mainly occurs through inhalation and skin contact during production, formulation, and agricultural usage. Pesticides can be divided into insecticides (organophosphates, such as parathion and malathion and cyclic chlorinated pesticides such as DDT), herbicides (for example 2,4-D and 2,4,5-T), halogenated aliphatic pesticides used as fumigants (for example, methylbromide) and fungicides (mostly mercury compounds). ${ }^{1427} 28$ Studies with experimental animals encompassing several insecticides suggested fetotoxic effects at high doses, and altered learning patterns and behavioural effects at concentrations below those experienced in occupational exposure. ${ }^{145582}$ Prenatal exposure of rats to low concentrations of 2,4,5-T also led to long term effects on behaviour, ${ }^{83} 84$ and exposure to the fungicide benomyl caused craniocerebral malformations. ${ }^{85} 86$

Studies on reproductive outcome in humans referred particularly to parental exposure to herbicides. $^{8788}$ Several studies suggested a possible increase in birth defects but a greater occurrence of 
malformations of the CNS was not found. One case report described a child with severe mental retardation that may have been related to parental exposure to $2,4-D .^{89}$ No clear associations were found between congenital malformations and exposure to dioxins, ${ }^{9091}$ agricultural workers, ${ }^{9293}$ or exposure to other pesticides. ${ }^{1114}$ High concentrations of some insecticides are excreted in maternal milk but no effects were described in breast fed infants. ${ }^{14}$ Studies on laboratory animals suggested that various pesticides have teratogenic effects on the developing CNS but studies on humans were inconclusive regarding the risks of parental occupational exposure. The effects of exposure to low doses of pesticides in humans are difficult to investigate, however, because of the problem of finding pesticide free control populations. $^{9}$

\section{OTHER OCCUPATIONAL CHEMICALS}

Among the heavy metals, occupational exposure to arsenic could be seen as possibly teratogenic to the CNS, in addition to lead, mercury, and cadmium. A few studies on animals described congenital abnormalities including exencephaly. ${ }^{55}$ In studies on humans conducted in the vicinity of a metal smelter in Sweden, ${ }^{14}$ increased frequencies of congenital malformations were found but defects of the CNS were not specified. Arsenic may not have been the only substance responsible for these findings.

In the plastic and rubber industry, some agents, such as vinyl chloride, styrene and chloroprene, are suspected of being teratogenic, but contradictory reports about the occurrence of defects of the CNS in offspring ${ }^{14}$ do not allow us to draw conclusions.

Effects of polychlorinated biphenyls (PCBs) used in the manufacture of plastics, condensers, and batteries, have been described for both prenatal and postnatal exposure. Behavioural and developmental abnormalities after transplacental exposure were found in animals ${ }^{9495}$ and children. ${ }^{9697}$ The transfer of PCBs through breast milk, however, is probably more important than placental transfer. ${ }^{914}$ Breast fed children showed higher serum PCBs and some neurological impairment. ${ }^{989}$ A similar association was suggested between polybrominated biphenyls (PBBs) and developmental abilities in children. ${ }^{100} \mathrm{~A}$ relation with parental occupational exposure to PCBs or PBBs has not been described, but cannot be ruled out.

\section{RADIATION}

Exposure to ionising radiation is an issue in many occupations, not only in nuclear power plants and radiography departments in hospitals, but also in the construction industry, the chemical and pharmaceutical industries, in food processing, and in research. Ionising radiation is known to cause genetic defects, but it may also exert a direct effect on the fetus leading to microcephaly, mental retardation, and growth retardation. ${ }^{101} 102$ The most relevant information on prenatal exposure in humans was found in studies on the survivors of the atomic bombs in Japan. ${ }^{103-106}$ Obvious relations were found between the above mentioned effects and exposure to doses of over $50 \mathrm{rad}$. The most radiosensitive period seems to be between eight and 15 weeks of gestation, the period in which rapid proliferation and migration of neuroblasts occurs. If the fetus is exposed to ionising radiation before week eight or after week 20 of gestation, only minor effects on the CNS are to be expected. ${ }^{101}$ These results were confirmed in studies on experimental animals ${ }^{107}$ in which gross malformations of the $\mathrm{CNS}^{108-110}$ and behavioural effects were also found. ${ }^{11112}$ The behavioural changes were associated with low doses of ionising radiation. Indications of effects of low doses on the developing CNS were reported for humans after diagnostic or therapeutic irradiation of the mother during gestation, ${ }^{113-115}$ although recent studies on exposure to environmental radiation failed to show any increase in congenital malformations. ${ }^{116}{ }^{117}$ Postnatal exposure to ionising radiation was associated with impairments in the CNS in only one study. ${ }^{118}$ Reports of studies on parental occupational exposure have not been found, but the available evidence indicates that effects on the fetal CNS are possible, even at low levels of ionising radiation.

Studies of the effects of non-ionising radiation, such as microwaves and radio frequencies, on humans did not show any CNS or other congenital defects. Behavioural changes were found in rats after prenatal radiation with microwaves. ${ }^{119-121}$

\section{Summary and conclusions}

The effects of exposure to agents used occupationally on the developing CNS are summarised in the table. On the basis of the information available (number and quality of studies combined with the results) a classification is made into obvious, probable, and possible effects. "Negative" studies were not taken into account in this review. For most agents, a number of studies with experimental animals have been performed, which provide relatively straightforward evidence regarding both morphological and behavioural abnormalities. High levels of exposure were often used in these studies, however, and the reliability of extrapolation to defects in the CNS of humans is questionable. Studies on humans include epidemiological surveys, large case series, and also single case reports that mostly refer to environmental "accidents" with exposure to high doses. Few epidemiological studies were found and some showed methodological shortcomings. The case reports only gave tentative indications of defects; larger case series were more informative in this respect. The results from the different types of study, which often yielded 
Summary of effects of prenatal and postnatal exposure on developing brain, classified as obvious, probable, or possible

\begin{tabular}{|c|c|c|c|c|c|c|c|}
\hline \multirow[b]{2}{*}{ Exposure category } & \multirow[b]{2}{*}{ Period (pre or postnatal) } & \multicolumn{2}{|c|}{$\begin{array}{l}\text { Effects in } \\
\text { experimental } \\
\text { animal studies }\end{array}$} & \multicolumn{2}{|c|}{$\begin{array}{l}\text { Effects in } \\
\text { envirommental } \\
\text { studies }\end{array}$} & \multicolumn{2}{|c|}{$\begin{array}{l}\text { Effects in } \\
\text { occupational } \\
\text { studies }\end{array}$} \\
\hline & & $S^{\star}$ & $F^{\star}$ & $S^{\star}$ & $F^{\star}$ & $S^{\star}$ & $F \star$ \\
\hline Lead & $\begin{array}{l}\text { pre } \\
\text { post }\end{array}$ & ++ & + & \pm & $\begin{array}{l}++ \\
++\end{array}$ & & \\
\hline Methylmercury & $\begin{array}{l}\text { pre } \\
\text { post }\end{array}$ & ++ & ++ & ++ & ++ & & \\
\hline Other mercury & $\begin{array}{l}\text { pre } \\
\text { post }\end{array}$ & & \pm & & & \pm & \\
\hline Cadmium & $\begin{array}{l}\text { pre } \\
\text { post }\end{array}$ & + & + & & \pm & & \\
\hline Organic solvents & $\begin{array}{l}\text { pre } \\
\text { post }\end{array}$ & & + & & \pm & $+t$ & \\
\hline Anaesthetics & $\begin{array}{l}\text { pre } \\
\text { post }\end{array}$ & & $\begin{array}{l}+ \\
+\end{array}$ & & & \pm & \pm \\
\hline Pesticides & $\begin{array}{l}\text { pre } \\
\text { post }\end{array}$ & ++ & ++ & & \pm & & \\
\hline PCB or PBB & $\begin{array}{l}\text { pre } \\
\text { post }\end{array}$ & & + & & $\begin{array}{l}+ \\
+\end{array}$ & & \\
\hline Ionising radiation & $\begin{array}{l}\text { pre } \\
\text { post }\end{array}$ & $+t$ & ++ & ++ & $\begin{array}{l}+t \\
\pm\end{array}$ & & \\
\hline
\end{tabular}

$++=$ Obvious; $t=$ probable; $\pm=$ possible.

$\star S=$ Structural CNS defects; $F=$ functional CNS defects.

†Including paternal exposure and brain tumours.

contradictory or inconsistent information, are weighted in the classification in the table. Studies on occupational exposure were scarce and most of them addressed congenital malformations as such, sometimes highlighting defects of the CNS. Unfortunately, a broad range of exposures or occupations were often evaluated, making these studies inconclusive.

Despite the large number of papers addressing this subject in general, there is no direct evidence that defects of the CNS in offspring are associated with parental occupational exposure during gestation. The information obtained from non-occupational studies, in which a scala of structural and functional defects of the CNS were found, is inadequate to form sound conclusions about occupational exposure, but some hypotheses may be formulated. A causal role of parental occupational exposure in the origin of defects of the CNS is:

probable, for lead, (methyl) mercury, and ionis-

ing radiation;

possible, for cadmium, organic solvents, anaes-

thetics and pesticides;

not to be excluded, for other chemicals and non-

ionising radiation.

There are still large gaps in our knowledge on the influence of parental occupational exposure on the developing CNS that call for well designed future research. So far, most studies have referred to broad categories of exposure and effects, which usually lead to misclassification obscuring any possible evidence of an association. Future research should focus on relating specific exposures to specific effects, with the emphasis on the validity of estimation of exposure and assessment of outcome. The available evidence at this moment stresses the urgent need to test hypotheses regarding a causal role of parental occupational exposure to the agents described above in the origin of defects of the CNS in offspring.

We express our special thanks to $\mathrm{R} L \mathrm{Zielhuis}$ for his useful comments on the manuscript.

Requests for reprints to: $N$ Roeleveld MSc, Department of Epidemiology, Institute of Social Medicine, University of Nijmegen, PO Box 9101, 6500 HB Nijmegen, the Netherlands.

1 Ornoy A, Yanai J. Central nervous system teratogenicity: experimental models for human problems. In: Persaud TVN, ed. Neural and behavioural teratology. Advances in the study of birth defects. Vol 4. Lancaster: MTP Press, 1980: $1-21$.

2 Kameyama Y. Factors in manifestation of developmental abnormalities of the central nervous system by environmental agents. J Toxicol Sci 1983;8:91-103.

3 Langman J, Webster W, Rodier P. Morphological and behavioural abnormalities caused by insults to the CNS in the prenatal period. In: Berry CL, Poswillo DE, eds. Teratology, trends and applications. Berlin: Springer, 1975: 182-200.

4 Coyle I, Wayner MJ, Singer G. Behavioural teratogenesis: a critical evaluation. In: Persaud TVN, ed. Neural and behavioural teratology. Advances in the study of birth defects. Vol 4. Lancaster: MTP Press, 1980:111-33.

5 Miller RK. Perinatal toxicology: its recognition and fundamentals. Am J Ind Med 1983;4:205-44.

6 Swaab DF, Mirminen M. Possible mechanisms underlying the teratogenic effects of medicines on the developing brain. In: Yania J, ed. Neurobehavioural Teratology. Amsterdam: Elsevier Science Publishers, 1984:55-71.

7 Joffe JM, Soyka LF. Paternal drug exposure: effects on reproduction and progeny. Semin Perinatol 1982;6:116-24.

8 Legator MS, Ward JB Jr. Genetic toxicology-relevant studies 
with animals and humans. In: Lockey JE, Lemasters GK, Keye WR Jr, eds. Reproduction: the new frontier in occupational and environmental health research. Progress in clinical and biological research. Vol 160. New York: Alan R Liss Inc, 1984:491-525.

9 Longo LD. Environmental pollution and pregnancy: risks and uncertainties for the fetus and infant. Am J Obstet Gynecol 1980;137:162-73.

10 Kalter H, Warkany J. Congenital malformations: etiologic factors and their role in prevention (two parts). $N$ Engl J Med 1983;308:424-31, 491-7.

11 Hemminki K, Vineis P. Extrapolation of the evidence on teratogenicity of chemicals between humans and experimental animals: chemicals other than drugs. Teratogenesis Carcinog Mutagen 1985;5:251-318.

12 Rodier PM, Reynolds SS, Roberts WN. Behavioural consequences of interference with CNS development in the early fetal period. Teratology 1979;19:327-36.

13 Dobbing J. The later development of the brain and its vulnerability. In: Davies JA, Dobbing J, eds. Scientific foundation of pediatrics. London: Heineman, 1981:741-59.

14 Zielhuis RL, Stijkel A, Verberk MM, Poel-Bot $M$ van de. Health risks to female workers in occupational exposure to chemical agents. Heidelberg: Springer Verlag, 1984.

15 Barlow SM, Sullivan FM. Reproductive hazards and industrial chemicals. Ann Occup Hyg 1981;24:359-61.

16 Rosenberg MJ, Feldblum PJ, Marshall EG. Occupational influences on reproduction: a review of recent literature. $J$ Occup Med 1987;29:584-91.

17 Shaw GM, Gold EB. Methodological considerations in the study of parental occupational exposures and congenital malformations in offspring. Scand J Work Environ Health 1988;14:344-55.

18 Erickson JD, Cochran WM, Anderson CE. Parental occupation and birth defects. Contributions to Epidemiology and Biostatistics 1979;1:107-17.

19 Hemminki K, Mutanen P, Saloniemi I, Luoma K. Congenital malformations and maternal occupation in Finland: multivariate analysis. J Epidemiol Community Health 1981;35: 5-10.

20 Holmberg PC, Hernberg S. Congenital defects and occupational factors. A comparison of different methodological approaches. Scand J Work Environ Health 1979;5:328-32.

21 Hemmink' K, Saloniemi I, Salonen T, Partanen T, Vainio H. Childhood cancer and parental occupation in Finland. $J$ Epidemiol Community Health 1981;35:11-15.

22 Peters JM, Preston-Martin S, Yu MC. Brain tumors in children and occupational exposure of parents. Science 1981;213:235-7.

23 Olshan AF, Breslow NE, Daling JR, Weiss NS, Leviton A. Childhood brain tumors and paternal occupation in the aerospace industry. $J$ Natl Cancer Inst 1986;77:17-9.

24 Johnsson CC, Annegers JF, Frankowski RF, Spitz MR, Buffler PA. Childhood nervous system tumors. An evaluation of the association with paternal occupational exposure to hydrocarbons. Am J Epidemiol 1987;126:605-13.

25 Nasca PC, Baptiste MS, MacCubbin PA, et al. An epidemiologic case-control study of central nervous system tumors in children and parental occupational exposures. $\mathrm{Am} \mathrm{J}$ Epidemiol 1988;128:1256-65.

26 Wilkins JR III, Koutras RA. Paternal occupation and brain cancer in offspring: a mortality-based case-control study. $\mathrm{Am}$ $J$ Ind Med 1988;14:299-318.

27 Zenz C, ed. Development in occupational medicine. Chicago: Year Book Medical Publishers Inc, 1981.

28 Rom WN, ed. Environmental and occupational medicine. Boston: Little, Brown and Co, 1983.

29 Beattie AD, Moore MR, Goldberg A, et al. Role of chronic lowlevel lead exposure in the aetiology of mental retardation. Lancet 1975 ; i:589-92.

30 Gerber GH, Léonard A, Jacquet P. Toxicity, mutagenicity and teratogenicity of lead. Mutation Research 1980;76:115-41.

31 Lödgberg B, Berlin M, Schütz A. Effects of lead exposure on pregnancy outcome and the fetal brain of squirrel monkeys. Scand J Work Environ Health 1987;13:135-45.

32 Gelder GA van, Carson T, Smith RM, Buch WB. Behavioral toxicologic assessment of the neurologic effect of lead in sheep. Clinical Toxicology 1973;6:405.

33 Brady $K$, Herrera $Y$, Zenick $H$. Influence of paternal lead exposure on subsequent learning ability of offspring. Pharmacol Biochem Behav 1975;3:561-5.

34 National Academy of Sciences. Lead: airborne lead in perspective. Washington DC: National Research Council, 1972:162.
35 Needleman HL, Rabinowitz M, Leviton A, et al. The relationship between prenatal exposure to lead and congenital abnormalities. JAMA 1984;251:2956-9.

36 Moore MR, Meredith PA, Goldberg A. A retrospective analysis of blood-lead in mentally retarded children. Lancet 1977;i:717-9.

37 Clarkson TW, Nordberg GF, Sager PR. Reproductive and developmental toxicity of metals. Scand $J$ Work Environ Health 1985;11:145-54.

38 Bellinger D, Leviton A, Waternaux C, Needleman H, Rabinowitz $M$. Longitudinal analyses of prenatal and postnatal lead exposure and early cognitive development. $N$ Engl J Med 1987;316:1037-43.

39 Rutter M. Raised lead levels and impaired cognitive/ behavioural functioning: a review of the evidence. Dev Med Child Neurol 1980;22:1-26 (suppl 1).

40 Yule W, Lansdown R, Millar IB, Urbanowicz M-A. The relationship between blood lead concentrations, intelligence and attainment in a school population: a pilot study. Dev Med Child Neurol 1981;23:567-76.

41 Marlowe M, Errera J, Jacobs J. Increased lead and cadmium burdens among mentally retarded children and children with borderline intelligence. Am J Ment Defic 1983;87:477-83.

42 Needleman HL. Lead at low dose and the behavior of children. Acta Psychiatr Scand 1983;67:26-37 (suppl 303).

43 Hawk BA, Schroeder SR, Robinson G, et al. Relation of lead and social factors to IQ of low-SES children: a partial replication. Am J Ment Defic 1986;91:178-83.

44 Wigg NR, Vimpani GV, McMichael AJ, Baghurst PA, Robertson EF, Roberts RJ. Port Pirie cohort study: childhood blood lead and neuropsychological development at age two years. J Epidemiol Community Health 1988;42:213-9.

45 Fulton M, Thomson G, Hunter R, Raab G, Laxen D, Hepburn W. Influence of blood lead on the ability and attainment of children in Edinburgh. Lancet 1987;i:1221-6.

46 Chang LW, Annau Z. Developmental neuropathology and behavioral teratology of methylmercury. In: Yanai J, ed. Neurobehavioral Teratology. Amsterdam: Elsevier, 1984: 405-32.

47 Choi BH. Methylmercury poisoning of the developing nervous system: I. Pattern of neuronal migration in the cerebral cortex. Neurotoxicology 1986;7:591-600.

48 Bartolome J, Whitmor WL, Seidler FJ, Slotkin TA. Exposure to methylmercury in utero: effects on biochemical development of catecholamine neurotransmitter systems. Life Sci 1984;35:657-70.

49 Slotkin TA, Pachman S, Kavlock RJ, Bartolome J. Early biochemical detection of adverse effects of a neurobehavioral teratogen: influence of prenatal methylmercury exposure on ornithine decarboxylase in brain and other tissues of fetal and neonatal rat. Teratology 1985;32:195-202.

50 Wootten V, Brown DR, Callahan BG, et al. Behavioral and biochemical alterations following in utero exposure to methylmercury. Neurobehavioral Toxicology and Teratology 1985;7:767-73.

51 Harada $M$. Neuropsychiatric disturbances due to organic mercury poisoning during the prenatal period. Folia Psychiatrica et Neurologia Japonica 1964;66:426-8.

52 Amin-Zaki L, Elhassani SB, Majeed MA, et al. Intrauterine methylmercury poisoning in Iraq. Pediatrics 1974;54: 587-95.

53 Koos BJ, Longo LD. Mercury toxicity in the pregnant woman, fetus and newborn infant. Am J Obstet Gynecol 1976; 126:390-409.

54 Reuhl KR, Chang LW. Effects of methylmercury on the development of the nervous system: a review. Neurotoxicology 1979;1:21-55.

55 Council on Environmental Quality. Chemical hazards to human reproduction. Washington DC: Clement Associates Inc, 1981.

56 Léonard A, Jacquet P, Lauwerys RR. Mutagenicity and teratogenicity of mercury compounds. Mutation Research 1983;114:1-18.

57 Shimai S, Satoh H. Behavioral teratology of methylmercury. J Toxicol Sci 1985;10:199-216.

58 Melkonian R, Baker D. Risks of industrial mercury exposure in pregnancy. Obstet Gynecol Surv 1988;43:637-41.

59 Gelbier S, Ingram J, Possible foetotoxic effects of mercury vapour: a case report. Public Health 1989;103:35-40.

60 Carmichael NG, Backhouse BL, Winder C, Lewis PD. Teratogenicity, toxicity and perinatal effects of cadmium. Hum Toxicol 1982;1:159-85.

61 Rastogi RB, Merali Z, Singhal RL. Cadmium alters behavior 
and the biosynthetic capacity for catecholamines and serotonin in neonatal rat brain. JNeurochem 1977;28:789-94.

62 Nelson BK, Taylor BJ, Setzer JV, Hornung RW. Behavioral teratology of perchloroethylene in rats. J Environ Pathol Toxicol 1980;3:233-50.

63 Nelson BK, Brightwell WS. Behavioral teratology of ethylene glycol monomethyl and monoethyl ethers. Environ Health Perspect 1984;57:43-6.

64 Taylor DH. Lagory KE, Zaccaro DJ, Pfohl RJ, Laurie RD. Effect of trichloroethylene on the exploratory and locomotor activity of rats exposed during development. Science of the Total Environment 1985;47:415-20.

65 Toutant C, Lippmann S. Fetal solvents syndrome. Lancet 1979;i:1356.

66 Hersh JH, Podruch PE, Rogers G, Weisskopf B. Toluene embryopathy. J Pediatr 1985;106:922-7.

67 Meirik O, Källén B, Gauffin U, Ericson A. Major malformations in infants born of women who worked in laboratories while pregnant. Lancet 1979;ii:91.

68 Hansson E, Jansa S, Wande H, Källèn B, Ostlund E. Pregnancy outcome for women working in laboratories in some of the pharmaceutical industries in Sweden. Scand $J$ Work Environ Health 1980;6:131-4.

69 Blomqvist U, Ericson A, Källén B, Westerholm P. Delivery outcome for women working in the pulp and paper industry. Scand J Work Environ Health 1981;7:114-8.

70 Axelsson G, Lütz C, Rylander R. Exposure to solvents and outcome of pregnancy in university laboratory employees. $\mathrm{Br} J$ Ind Med 1984;41:305-12.

71 Holmberg PC, Nurminen MN. Congenital defects of the central nervous system and occupational factors during pregnancy $A m J$ Ind Med 1980;1:167-76.

72 Kurppa $\mathrm{K}$, et al. Screening for occupational exposures and congenital malformations. Preliminary results from a nationwide case-referent study. Scand J Work Environ Health 1983;9:89-93.

73 Eskenazi B, Gaylord L, Bracken MB, Brown D. In utero exposure to organic solvents and human neurodevelopment. Dev Med Child Neurol 1988;30:492-501.

74 Olsen J. Risk of exposure to teratogens amongst laboratory staff and painters. Dan Med Bull 1983;30:24-8.

75 Edling C. Anesthetic gases as an occupational hazard-a review. Scand J Work Environ Health 1980;6:85-93.

76 Vessey MP, Nunn JF. Occupational hazards of anaesthesia. Br Med J 1980;281:696-8.

77 Tannenbaum TN, Goldberg RJ. Exposure to anesthetic gases and reproductive outcome. JOccup Med 1985;27:659-68.

78 Tomlin PJ. Health problems of anaesthetists and their families in the West Midlands. Br Med J 1979;278:779-84.

79 Bowman RE, Smith RF. Behavioral and neurochemical effects of prenatal halothane. Environ Health Perspect 1977;21: $189-93$.

80 Koëter HBWM, Rodier PM. Functional development of mice after pre-and postnatal exposure to inhalant anesthetics. Paper presented during the 1981 meeting of the European Teratology Society. Basel, 1981.

81 Tabacova S, Nikiforov B, Balabaeva L. Postnatal effects of maternal exposure to nitrogen dioxide. Neurobehavioral Toxicology and Teratology 1985;7:785-9.

82 Gupta RC, Rech RH, Lovell KL, Welsch F, Thornburg JE. Brain cholinergic, behavioral, and morphological development in rats exposed in utero to methylparathion. Toxicol Appl Pharmacol 1985;77:405-13.

83 Crampton MA, Rogers LJ. Low doses of 2,4,5-trichlorophenoxyacetic acid are behaviorally teratogenic to rats. Experientia 1983;39:891-2.

84 Mohammad FK, St Omer VE. Behavioral and developmental effects in rats following in utero exposure to 2,4-D/2,4,5-T mixture. Neurobehavioral Toxicology and Teratology 1986; 8:551-60.

85 Zeman FJ, Hoogenboom ER, Kavlock RJ, Semple JL. Effects on the fetus of maternal benomyl exposure in the proteindeprived rat. $J$ Toxicol Environ Health 1986;17:405-17.

86 Ellis WG, Semple JL, Hoogenboom ER, Kavlock RJ, Zeman FJ. Benomyl-induced craniocerebral anomalies in fetuses of adequately nourished and protein-deprived rats. Teratogenesis Carcinog Mutagen 1987;7:357-75.

87 Constable JD, Hatch MC. Reproductive effects of herbicide exposure in Vietnam: recent studies by the Vietnamese and others. Teratogenesis Carcinog Mutagen 1985;5:231-50.

88 Sterling TD, Arundel AV. Health effects of phenoxy herbicides. Scand J Work Environ Health 1986;12:161-73.

89 Casey PH, Collie WR. Severe mental retardation and multiple congenital anomalies of uncertain cause after extreme parental exposure to 2,4-D. J Pediatr $1984 ; 104: 313-5$.

90 Townsend EC, et al. Survey of reproductive events of wives of employees exposed to chlorinated dioxins. Am J Epidemiol 1982;115:695-713.

91 Stockbauer JW, Hoffman RE, Schramm WF, Edmonds LD. Reproductive outcomes of mothers with potential exposure to 2,3,7,8-tetrachloro-dibenzo-p-dioxin. Am J Epidemiol 128:410-9.

92 Balarajan R, McDowall M. Congenital malformations and agricultural workers. Lancet 1983;i:1112-3.

93 Schwartz DA, Newsum LA, Markowitz Heifetz R. Parental occupation and birth outcome in an agricultural community. Scand J Work Environ Health 1986;12:51-4.

94 Geller I, Hartmann RJ, Garcia C. Effects of polybrominated biphenyl on a discrimination task in rats. Neurobehavioral Toxicology and Teratology 1979;1:263-7.

95 Bowman RE, Heironimus MP, Barsotte DA. Locomotor hyperactivity in PCB-exposed rhesus monkeys. Neurotoxicology 1981;2:251-68.

96 Rogan WJ, Gladen BC, McKinney D, et al. Neonatal effects of transplacental exposure to PCBs and DDE. J Pediatr 1986; 109:335-41.

97 Gladen BC, Rogan WJ, Hardy P, Thullen J, Tingelstad J, Tully $M$. Development after exposure to polychlorinated biphenyls and dichlorodiphenyl dichoroethene transplacentally and through human milk. J Pediatr 1988;113:991-5.

98 Rogan W, Bagniewska A, Damstra T. Pollutants in breast milk. N Engl J Med 1980;302:1450-3.

99 Jacobson JL, Fein GG, Jacobson SW, Schwartz PM, Dowler JK. The transfer of polychlorinated biphenyls (PCBs) and polybrominated biphenyls (PBBs) across the human placenta and into maternal milk. Am J Public Health 1984;74:378-9.

100 Walker Seagull EA. Developmental abilities of children exposed to polybrominated biphenyls (PBB). Am J Public Health 1983;73:281-5.

101 Mole RH. Consequences of pre-natal radiation exposure for post-natal development. A review. Int J Radiat Biol 1982; 42:1-12.

102 Brent RL. The effects of embryonic and fetal exposure to $x$-ray microwaves and ultrasound. Clin Obstet Gynecol 1983;26:484-510.

103 Wood JW, Keehn RJ, Kawamoto S, Johnson KG. The growth and development of children exposed in utero to the atomic bombs in Hiroshima and Nagasaki. Am J Public Health 1967;57:1374-80.

104 Wood JW, Johnson KG, Omori Y, Kawamoto S, Keehn RJ. Mental retardation in children exposed in utero to the atomic bombs in Hiroshima and Nagasaki. Am J Public Health 1967;57:1381-90.

105 Blot WJ, Miller RW. Mental retardation following in utero exposure to the atomic bombs of Hiroshima and Nagasaki. Radiology 1973;106:617-9.

106 Otake M, Schull WJ. In utero exposure to A-bomb radiation and mental retardation: a reassessment. Br J Radiol 1984; 57:409-14

107 Hicks SP, d'Amato CJ. Effects of ionizing radiation on developing brain and behavior. In: Gottlieb G, ed. Studies on the development of behavior and the nervous system. Early Influences. Vol 4. New York: Academic Press, 1984:34-72.

108 Ferrer I, Xumetra A, Santamaria J. Cerebral malformation induced by prenatal $\mathrm{X}$-irradiation: an autoradiographic and Golgi study. J Anat 1984;138:81-93.

109 Friedberg W, Faulkner DN, Neas BR, et al. Dose-incidence relationships for exencephalia, anophthalmia and prenatal mortality in mouse embryos irradiated with fission neutrons or $250 \mathrm{kv}$ X-rays. Int J Radiat Biol 1987;52:223-36.

110 Schmidt SL, Lent R. Effects of prenatal irradiation on the development of cerebral cortex and corpus callosum of the mouse. J Comp Neurol, 1987;264:193-204.

111 Norton S. Behavioral changes in preweaning and adult rats exposed prenatally to low ionizing radiation. Toxicol Appl Pharmacol 1986;83:240-9.

112 Jensh RP, Brent R, Vogel WH. Studies on the effect of 0.4-Gy and $0.6-G y$ prenatal $X$-irradiation on postnatal adult behavior in the Wistar rat. Teratology 1987;35:53-61.

113 Granroth G. Defects of the central nervous system in Finland. IV: Associations with diagnostic X-ray examinations. $\mathbf{A m} \mathbf{J}$ Obstet Gynecol 1979;133:191-4.

114 Mole RH. Radiation effects on pre-natal development and their radiological significance. $B r J$ Radiol 1979;52:89-101.

115 Meyer MB, Tonacia J. Long-term effects of prenatal X-ray of human females. II. Growth and development. $A m J$ 
Epidemiol 1981;114:317-26.

116 Sever LE, Gilbert ES, Hessol NA, McIntyre JM. A casecontrol study of congenital malformations and occupational exposure to low-level ionizing radiation. Am J Epidemiol 1988;127:226-42.

117 Harjulehto T, Aro T, Rita $H$, Rytömaa T, Saxén L. The accident at Chernobyl and outcome of pregnancy in Finland. Br Med J 1989;298:995-7.

118 Ron E, Modan B, Floro S, Harkedar I, Gurewitz R. Mental function following scalp irradiation during childhood. Am J Epidemiol 1982;116:149-60.

119 Jensh RP, Vogel WH, Brent RL. An evaluation of the teratogenic potential of protracted exposure of pregnant rats to $2450-\mathrm{MHz}$ microwave radiation. II. Postnatal psychophysiologic analysis. J Toxicol Environ Health 1983;11: 37-59.

120 Jensh RP. Studies on the teratogenic potential of exposure of rats to $6000-\mathrm{MHz}$ microwave radiation. II. Postnatal psychophysiologic evaluations. Radiat Res 1984;97:282-301.

121 Galvin MJ, Tilson HA, Mitchell CL, Peterson J, McRee DI. Influence of pre- and postnatal exposure of rats to $2.45-\mathrm{Ghz}$ microwave radiation on neurobehavioral function. Bioelectromagnetics 1986;7:57-71.

Accepted 3 April 1990

\section{Vancouver style}

All manuscripts submitted to the $\mathrm{Br} J$ Ind Med should conform to the uniform requirements for manuscripts submitted to biomedical journals (known as the Vancouver style)

The $\mathrm{Br} J$ Ind Med, together with many other international biomedical journals, has agreed to accept articles prepared in accordance with the Vancouver style. The style (described in full in $\mathrm{Br}$ Med J, 24 February 1979, p 532) is intended to standardise requirements for authors.

References should be numbered consecutively in the order in which they are first mentioned in the text by Arabic numerals above the line on each occasion the reference is cited (Manson ${ }^{1}$ confirmed other reports $\left.{ }^{2-5} \ldots\right)$. In future references to papers submitted to the $B r J$ Ind Med should include: the names of all authors if there are six or less or, if there are more, the first three followed by $e t$ al; the title of journal articles or book chapters; the titles of journals abbreviated according to the style of Index Medicus; and the first and final page numbers of the article or chapter.

Examples of common forms of references are:

1 International Steering Committee of Medical Editors. Uniform requirements for manuscripts submitted to biomedical journals. Br Med J 1979;1:532-5.

2 Soter NA, Wasserman SI, Austen KF. Cold urticaria: release into the circulation of histamine and eosino-phil chemotactic factor of anaphylaxis during cold challenge. $N$ Engl J Med 1976;294:687-90.

3 Weinstein L, Swartz MN. Pathogenic properties of invading micro-organisms. In: Sodeman WA Jr, Sodeman WA, eds. Pathologic physiology: mechanisms of disease. Philadelphia: W B Saunders, 1974:457-72. 